\title{
Concert visits with the music class: A Salzburg case study
}

\section{A Cooperation project with varying goals, tasks and expectations}

\begin{abstract}
ANDREAS BERNHOFER*
Department for Music Education, Mozarteum University Salzbur, Austria

\section{THEMATIC ARTICLE}

Published online: July 20, 2020

(c) 2020 The Author(s)

ABSTRACT

Many European cities offer a vivid cultural landscape and numerous live-music opportunities. Some of the events aim at young audiences and develop cooperation projects with schools (Schwanse, 2003). The Schools@Concerts research project focuses on long-established cooperation projects between schools and concert hosts and tries to give insights into the structure of them. This article describes the Salzburg single case study, where besides the music teacher, the school students and the concert host also a didactics course from the music teacher training at the university is involved. By collecting data with interviews and questionnaires with all participating partners, the research group tries to outline the different roles within the cooperation project and compares the varying goals, tasks and expectations of the participating partners.
\end{abstract}

\section{KEYWORDS}

cooperation project, concert attendance, music class, concert host, single case study

*Corresponding author. E-mail: Andreas.bernhofer@moz.ac.at 


\section{MUSIC EDUCATION IN AUSTRIA}

Music in school is for the Austrian Government and the Ministry of Education a relevant issue but from time to time discussions start about reducing the number of lessons for art subjects. Austrian schools are in the lucky position, that all pupils have compulsory music lessons until the age of 14, and if they continue in high school, music is compulsory until the age of 16, optional until they finish school at the age of 18 (see Table 1). In comparison to other European countries, Austrian school curricula preserved a minimum number of music lessons in each single grade.

If you have a closer look at the extracurricular activities concerning music, these are not regulated by the national curricula. Every school has the possibility to use a certain amount of teaching hours for extracurricular activities and so the focus can be set by the school itself. If we have a look at the last column of Table 1, we can see, that there is a wide range of possible teaching hours for choir, instrumental ensembles or other optional musical subjects. On the other hand, it is also possible for Austrian schools that there is no choir or instrumental ensemble taking place, because the particular school uses these hours for sports, natural science, languages, theater, etc. Schools use this freedom of choice to develop a unique profile to attract

Table 1. Distribution of music lessons in Austrian schools

\begin{tabular}{|c|c|c|c|}
\hline $\begin{array}{l}\text { Type of school } \\
\text { (age) }\end{array}$ & Obligatory (h) & Optional (h) & Exceeding (h) \\
\hline Preschool (3-6) & $\begin{array}{l}\text { - Singing, music-making } \\
\text { (41/2 per week) } \\
\text { - Rhythmical music education } \\
\text { (3-4 } 4^{1 / 2} \text { per week) }\end{array}$ & & \\
\hline $\begin{array}{l}\text { Primary School } \\
\quad(6-10)\end{array}$ & 4 ( $1 \mathrm{~h}$ each year $)$ & & $\begin{array}{l}\text { - Choir (4-8) } \\
\text { - Instrumental } \\
\text { ensemble (4-8) } \\
\text { - Music-making } \\
\quad(4-8)\end{array}$ \\
\hline $\begin{array}{l}\text { Secondary School } \\
\quad \text { I }(10-14)\end{array}$ & $6-7$ & & $\begin{array}{l}\text { - Choir }(2-8) \\
\text { - Instrumental } \\
\text { ensemble }(2-8)\end{array}$ \\
\hline $\begin{array}{l}\text { Secondary School } \\
\text { II }(14-16)\end{array}$ & 3 & & $\begin{array}{l}\text { - Optional } \\
\text { subjects (4) } \\
\text { - Choir (2-4) } \\
\text { - Instrumental } \\
\text { ensemble (2-4) }\end{array}$ \\
\hline $\begin{array}{l}\text { Secondary School } \\
\text { II }(16-18)\end{array}$ & & $\begin{array}{l}\text { Pupils have } \\
\text { to choose } \\
\text { either music } \\
\text { or art (4) }\end{array}$ & \\
\hline
\end{tabular}

Source: http://menet.mdw.ac.at/menetsite/english/t_content3_1_1_at.html. 
students to come to their school. The musical extracurricular activities are mostly dedicated to music making like choir singing or instrumental ensembles. Hardly any hours are used for music listening or activities, which are connected to concert attendances. If concert visits in the school context take place, they are mostly part of the regular music lessons although they may take place at different time.

\section{CONCERT ATTENDANCES WITH THE MUSIC CLASS}

To justify a concert attendance as part of the music class, it is necessary in Austria that it is connected to the curriculum. One part of the national curriculum for music contains the competences, and there are several points which can be taken as reasons to attend a live-musicperformance. The main anchor point for concert visits is the following competence description: "ein öffentliches Musikangebot wahrnehmen und an Aufführungen mit adäquatem Verhalten teilnehmen" (to perceive a public music offer and take part at performances with adequate behavior) (Knaus et al., 2013, p. 15). This is a clear brief to get in contact with the cultural offerings and take the opportunity to learn about the cultural practices in the school environment. The simplest way to acquire this competence is to explore the cultural environment around the school area and take part in music performances of different kinds together with the music class. Besides this competence, there are several competence descriptions which do not have a direct connection to a concert attendance, but the complexity of a concert experience could support the achievement of them. One is connected to listening to music: "Mit gerichteter Aufmerksamkeit hören" (to listen with focused attention) (Knaus et al., 2013, p. 14). The attendance of a concert offers you an excellent opportunity to practice focused listening for a longer period of time, because usually concerts take longer than school lessons. A second competence which is connected to musical instruments can easily be practiced by attending a live-music-performance: "Instrumente visuell und akustisch erkennen und ihre Bau- und Spielweise beschreiben" (to recognize instruments visually and acoustically and to describe their construction and way of playing) (Knaus et al., 2013, p. 14). An ideal way to learn about different musical instruments is to watch them played live by professional musicians. Of course, learning how to play an instrument by yourself would be best, but for all the others it is beneficial to see them on stage. This competence also mentions the construction of the instruments, which you cannot see in a concert, but this part can be done during the music lessons in the context of a concert attendance. The last competence, which should be mentioned here is the development of a listening repertoire: "Aufbau eines Hörrepertoires" (Knaus et al., 2013, p. 21). Single concert visits will not be enough to achieve this competence, but regular attendances could contribute to this goal (Bernhofer, 2016a).

As we can see from the competences mentioned above, concert attendances could foster the acquisition of them in connection with music lessons in school, where repetition of the content and reflection can take place.

If we want to know more about the situation in school, there are no empirical data from the Austrian schools, how often concert visits are organized in the school context. This is strongly connected to the commitment of the music teacher and his/her willingness to organize them. For the music teacher, there are many obstacles to overcome to give the students the opportunity to attend a concert. If a teacher decides to visit a concert with his/her music class, there are 
several tasks to do besides the daily work in the class room. Mainly the organizational ones are the most challenging. If the concert is during school time, it is necessary to negotiate with teacher colleagues about using their lesson time or a possible swap of lessons. In Austrian schools where you have a lot of exams in the different subjects, it is really challenging to convince other teachers of the necessity and added value of a live-music experience (Bernhofer, 2016). If the music concert is in the evening, it is necessary for the teacher to ask for the permission of all the parents before tackling the concert visit project. In addition, the music teacher is responsible to organize the concert tickets as well as the transportation of the whole group to the concert hall and back home. For all of this, the music teacher is at the mercy of the school principal who needs to consent to the concert attendance. All in all, it would be helpful for the music teacher, if he/she would be supported to settle all these organizational tasks.

\section{THE SCHOOLS@CONCERTS-RESEARCH PROJECT}

To get deeper insights into school projects, where students attend concerts with their music class, the European research project Schools@Concerts ${ }^{1}$ focused on long-established cooperation projects between schools and concert hosts in different European cities. The group of eleven music education researchers agreed on the following criteria for the project selection: Each selected project should be a cooperation between a single music class (students at the age of 10-14) and a concert host. The common goal should be the attendance of a classical evening concert with music from the last 250 years and the visit should be combined with a pre- and/or post-workshop.

To investigate the different selected single cases (Yin, 2009), the research team developed collaboratively a set of data collection tools for the participating partners of each project. The survey instruments contained three different parts. It included pre-post questionnaires for the participating students to get to know more about their musical background and their concert experiences. The second part consisted of interview questions for the concert host $\&$ the music teacher to find out more about their goals and expectations in connection to the concert visit and the third part were group interviews with the students after the concert attendance about their concert experiences (Bernhofer, 2016b).

\section{THE SCHOOLS@CONCERTS SALZBURG CASE}

In Salzburg (Austria) was one project selected, where a more than ten years established cooperation of the Mozarteum Foundation with different high schools takes place. A specificity of this Salzburg case is, that there was also the Mozarteum University involved as a third partner in this cooperation. In this case, besides the involved concert host (Mozarteum Foundation), the music teacher and the students (from the high school), the Mozarteum university was planning and carrying out the preparatory workshops with the students. The workshops were conceptualized by music education students within a master's course for cooperative music didactics. Compared to other projects within the Schools@Concerts framework, where they had three

\footnotetext{
${ }^{1}$ You can find further details about the research project here: https://schoolsatconcerts.gitlab.io/.
} 


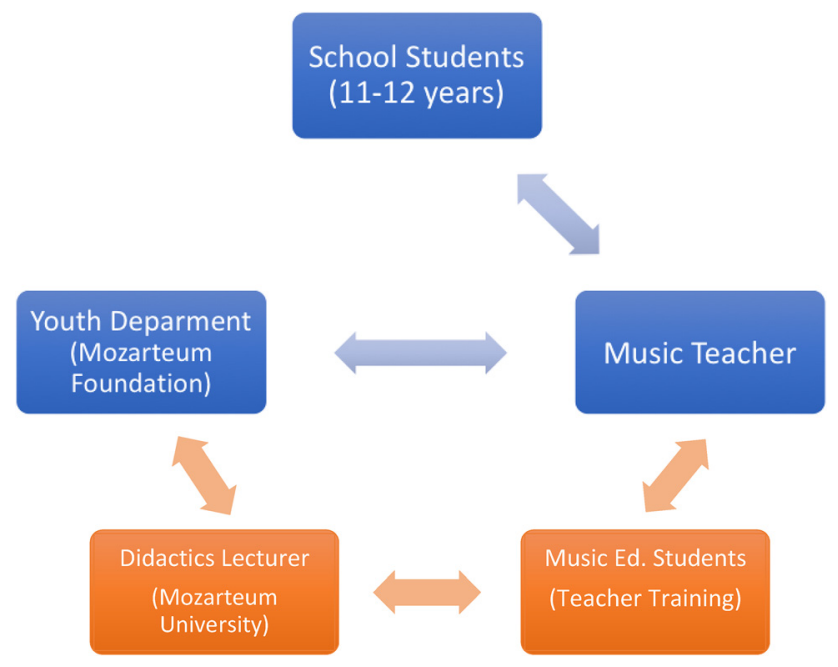

Fig. 1. Interaction and communication between the involved project partners

participating partners (Concert host, Music teacher \& Students), the Salzburg case had two extra partners involved (Didactics lecturer \& Music education students), who also interacted with the three others in specific ways. The didactics lecturer from Mozarteum University established together with the youth department of the Mozarteum foundation the cooperation between these two institutions. The music education students had the task to get in contact with the music teacher to clarify the framework conditions of the preparatory workshops in school. The music education students also conceptualized the workshop with the support of the didactics lecturer from the university and finally put the workshop into action with the students in the music class. The interaction connections are visualized by arrows in Fig. 1 and visualizes the communication between the different project partners. The music class from the Salzburg case was grade 6 of an urban secondary school and 21 school students (12 boys and 9 girls) participated in the project.

\section{ROLES AND TASKS WITHIN THE COOPERATION PROJECT}

Every partner in this cooperation had his/her role and contributed to the common goal of an inspiring and educational concert attendance for the young school students. From the different interviews with the participating partners in this project, it was possible to derive role descriptions and to show, how they interacted during the different stages of this complex project. We start with the description of the concert host's role. The concert host initiated the whole project when they decided to provide cheaper tickets to give young people the chance to attend their classical concerts. They were looking for a partner who is able to develop preparatory workshops for a young audience as introductions to a concert attendance at the world famous Mozartwoche around Mozart's birthday in January. Since the Mozarteum Foundation and the 
Mozarteum University were already cooperation partners in other projects and share a common history in Salzburg, the concert host contacted the head of the music education department about this idea of working together. From this point on, the concert host had mostly an organizational role. They were responsible for finding music classes who wanted to participate, they made the contact between the music teacher and the music education students, they offered a budget of $50 €$ for materials for the preparatory workshop and they finally provided excellent tickets for the classical concert for a very favorable price.

The music teacher's role in the cooperation is a very important one, because she searched for possibilities for her school students to attend a classical concert and she was willing to take care of all organizational challenges, which are combined with a concert visit in the evening outside the school. She also organized the room for the workshop and the time slot, when the workshop could take place. Furthermore, she provided music educational input, because the workshop content was agreed between the music education students and the music teacher. The teacher had the chance to express wishes about the workshop focus and the content, because it should have been in line with the music curriculum and the topics of the music class. The music teacher plays a kind of key role in this cooperation because she also was the link between the school students and the music education students from the university. She gave important educational and pedagogical advice about the work with her music class and about their prior knowledge about classical music.

The school students from the music class between the age of 11 and 12 had the learners' role. They were the main reason for the establishment of the whole cooperation project because all participating partners pursued the goal of enabling the students an enjoyable and educational concert experience. They participated in the workshop and the concert visit and gave feedback to the music education students about their workshop realization. The feedback was an important basis for the reflection of the university course after the concert attendance.

The didactics lecturer and music education students were responsible for the workshop part of this cooperation. The whole project was integrated in the course of the music education master's program and had a specific sequence of work phases during the time span of 5 months. Since this is an important specificity of the Salzburg case, the following part provides a detailed description of the music education master's course called 'Cooperative Music Didactics'. The word cooperative in the course title underlines the main focus of this course, where the music education students need to work in teams for the workshop development and they have to cooperate with the music teacher from the school and the concert host on organizational and content-related issues.

\section{WORK PHASES AND TASKS WITHIN THE 'COOPERATIVE MUSIC DIDACTICS' COURSE ${ }^{2}$ INTERLINKED WITH THE DIFFERENT STAGES OF THE COOPERATION PROJECT}

Towards the end of their music pedagogy studies at the Mozarteum Salzburg, students complete the course 'Cooperative Music Didactics', during which the cooperation with the Mozarteum Foundation takes place. This seminar is considered a type of 'blank card' in the Music Education

\footnotetext{
${ }^{2}$ You can find more details of this cooperation project as part of the teacher training courses in Oebelsberger and Bernhofer (2019).
} 
Table 2. Project phases and tasks for the master students

Plenary phase 1

Information about project partner (Mozarteum Foundation, Festival

'Mozartwoche' and the concerts), Communicating music to a young audience

("Musikvermittlung") and working with creative materials

and music

Work phase in groups 1 Musicological search for information about the chosen concert program

Plenary phase 2

Presentation of the results of the musicological search

Work phase in groups 2

Group coaching

Plenary phase 3

Concept development for the school students' workshop

Workshop phase

Individual meeting with each group and discussion about the workshop concept

Presentation of the workshop concepts

Plenary phase 4

Workshop implementation with one music class and concert visit

Final presentation and reflection on the whole project

curriculum in Salzburg, in which students should use their acquired knowledge with utmost creativity and independence in order to design workshops. After theoretical input is given in plenary sessions on music conveyance and workshop design ${ }^{3}$, students intensively study selected works of the 'Mozartwoche' in small groups and begin to develop approaches for teaching the musical pieces to children and adolescents. The Mozarteum Foundation then assigns each of the student teams with one school class for which the respective workshops are designed and later carried out. For the research project, one class was selected and further investigated. The fact that the workshops are held in different classes stimulates the process of reflection after the project. The work for the music education students starts with the initial phase of developing ideas and of coaching the individual teams by the course instructor and is followed by a presentation of the workshop concepts in a plenary session.

After planning the workshops, appointments are made with the allocated school classes at the respective schools, where, spanning about four lesson units, the workshops with the school students take place. At the end of the course, the contents of the workshops are presented by the student teams as part of a reflection process and the results are jointly discussed.

The course of the seminar described above is divided into several work phases, which alternate between plenary sessions and working time for the individual groups. The following table presents the process in its various phases with the corresponding contents and tasks in connection to the stages of the cooperation project (see Table 2).

As the table shows, students are presented with a wide range of different tasks:

- Musicological examination of the selected works

- Teamwork during the development of and reflection on the workshop

- Sharing knowledge with experienced teachers at the assigned school

- Organization of the workshop in cooperation with the Mozarteum Foundation

- Presentation of the various phases in a plenary session

The students group which developed the workshops for the music class visited them two times for a two-hour session. The first session dealt with Mozart's biography and the connection to the concert programme, which consisted of Mozart's Mass in c minor (KV 427). One week

${ }^{3}$ For example, the use of creative media in the classroom. 
later, the Master students worked out the characteristics of a music mass and in particular Mozart's composition for the second workshop session.

\section{GOALS AND EXPECTATIONS OF THE PROJECT PARTNERS}

An important part of the research project focused on the different goals and expectations of the involved project partners. The research group wanted to find out more about the reasons, why music teachers, concert hosts and school students choose to participate in a cooperation project connected to a concert visit. The different surveys and interviews included this question about the goals and expectations. Based on the empirical data, the research team developed collaboratively a coding system (Mayring, 2008) to analyze computer-assisted ${ }^{4}$ the different answers and to find out, which arguments are used by which project partner (music teacher, school students, concert host). Goals and expectations have many communalities, but some expectations are not goals for the project. To give one example: In the interview with the concert host, she talked about her expectations that the booking of the rooms for the workshop will be a challenge for her, but this would not be called a goal for this project. In summary, negative expectations would not be called project goals and so the research group decided to keep both terms. To have a better overview of the usage of the different goals and expectations, the research group chose three overlapping circles to make visible which arguments are used by which project partners. This kind of graphical presentation could be used for both, goals and expectations. The numbers in the different parts of the circles indicate the different fields, where arguments were used by the project partners (Fig. 2).

The center field (No. 1) aggregates arguments, which were used by all three project partners. All of them said, that they expect the concert attendance to be an atmospheric and a social experience. The teacher for example talked about the holistic side of a concert visit, where experiencing the music is combined with the atmosphere of a concert hall and the social aspects of being part of a big audience. Some students wrote in their questionnaires, that they expect many people there and they also pointed out, that it is positive for them to be there with their friends. Another expectation, which was verbalized by all three project partners, was, that the concert visit will be an educational experience. The students said that they expect to learn more about the music played and about the composer. The concert host mentioned, that the students will listen to musical pieces, which are not part of the common school repertoire, so that they will get to know new, for them unknown musical works. The goal of learning new things about the music was also mentioned by the music teacher as a main reason for attending a classical concert with the music class.

In field No. 2 we can find all arguments which were mentioned by the music teacher as well as the students. The students often talked about their excitement and curiosity and about what will a concert visit be like. One student wrote, "that it will be beautiful and will set me into another world" (AT-JOER16). The teacher also expected, that everyone would find something, which he/she is excited about during a concert visit. The students as well as the teacher mentioned that they expect the concert visit to be first of all a musical experience. The students wrote about their expectations of great music, very good sound and new melodies. The teacher

\footnotetext{
${ }^{4}$ The research team used the free online platform qcamap.org, which is specialized on Mayrings qualitative content analysis (Mayring, 2008). This platform allows different researchers to code the same empirical data with a previously developed coding system and also offers statistical analysis.
} 


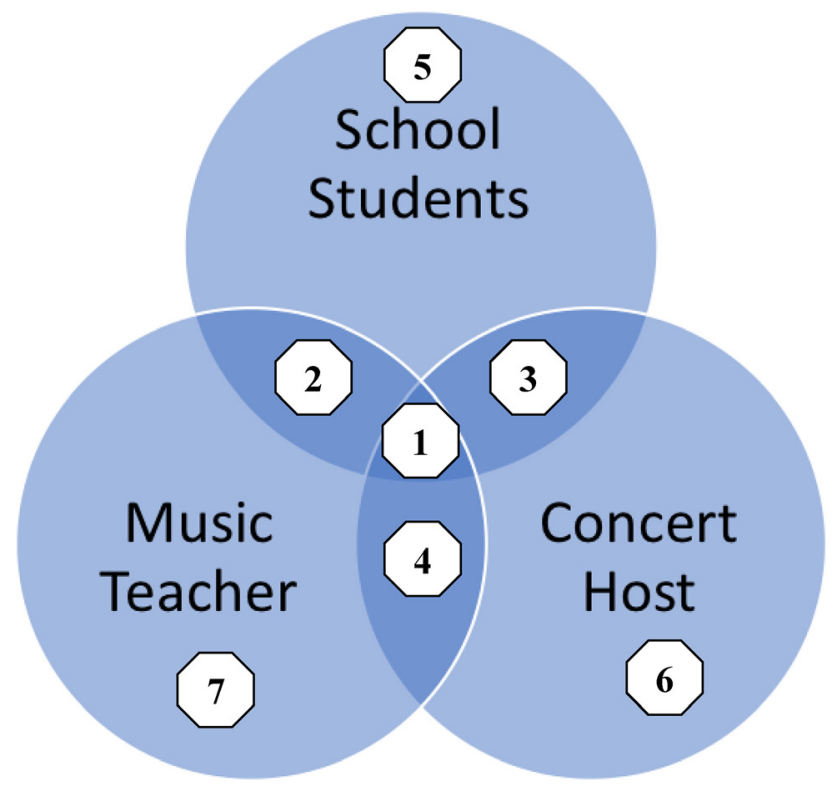

Fig. 2. Shared fields of goals and expectations of the project partners

verbalized her expectation and hope, "that the students experience classical music as a beautiful thing" (AT-Music Teacher).

The one thing, which belongs to field No. 3 was the students' and concert host's expectation of a better understanding of music. The host mentioned that students would listen differently to musical pieces if they previously attended a classical concert and one student wrote in the questionnaire, that music would be more understandable after a concert visit. (AT-MECH01) The music teacher did not talk about this issue during her interview.

Field No. 4 collects all arguments, which were mentioned by the music teacher and the host. Both verbalized their expectation that a live music experience have benefits for the young people and that live played classical music will have a positive effect on them. The teacher said, that she expects that the students will be touched by the music. The music teacher and the concert host mentioned the goal for this project, that students get the chance to make own experiences with the classical concert. They want to give the students the opportunity to attend such an event because for many students it would be the first time.

Finally, there are three fields left, where one project partner only verbalized these arguments. The concert host mentioned that she expects a lot of organizational work in coordinating dates and rooms for the workshop. She was also mentioning her task of dealing with data protection and image rights, which was a big issue for her. The music teacher mentioned the connection of the concert programme to the music curriculum as a reason for her to be part of this cooperation project. Another reason for her was that she wanted to do something outside of the classroom with her music class, to have extra time for the class community besides the music lessons. The concert 
host mentioned that a main reason for her institution is that the musicians want an age-mixing and that they want young people to be part of the audience in classical concerts. She also explained, that the Mozarteum Foundation wants to foster the music culture in Salzburg and the goal is to pass on the cultural values to the younger generation. From the students' side in field No. 5 could be said that some of them do not have any expectations or goals for the concert visit.

When we compare the Salzburg case with the other cooperation projects from the Schools@Concerts project, we can derive which aspects of the coding categories were not found in the Salzburg data. There were three categories not found: One category has to do with a transfer effect of music, that there are health benefits from attending a concert and listening to classical music. This one was mentioned in another project but none of the Salzburg project partners talked about this. From the British project we learned that one goal for the music teacher and the concert host in Birmingham was, that young people should be motivated to learn a musical instrument, when they attend a classical concert and watch the musicians play. They explained that the project is a kind of youth development, but nothing like this was mentioned from the Salzburg project partners. The third category, which was not found in the Salzburg data has to do with the concert programme. One concert host from another project explained that they do youth projects also for the musicians, because in these projects they can play more challenging musical pieces of contemporary music for a younger audience besides their concerts for the usual audience. The concert host from Salzburg mentioned that within their music festival, they play a lot of unfamiliar musical pieces, but she did not mention it as an explicit goal for the cooperation project.

During the analysis of the different interviews and questionnaires, there were some statements, which were not codable with the previously fixed coding guidelines. These statements should not be ignored, they give some interesting insights into the specificity of the Salzburg case. The interview with the concert host came to an interesting point when she was asked about pedagogical goals and financial goals. She negated both of them and explained, that the Mozarteum Foundation is not publically funded and so they are not linked to a pedagogical mission. She further explained, that they do not want to replace music education in school by fulfilling an educational mission. The cooperation project also did not have a financial goal, because they give very expensive tickets to the young audience for very cheap prices, although it would not be a problem for them to sell them for the regular price. She explained, that the Mozarteum Foundation has the main goal to make Mozart's music available for everybody. That is the reason for taking part in cooperation projects with young people.

During the interview with the music teacher, she talked about the organizational side of such cooperation projects. She mentioned that she asked the school principal and the other teachers for permission to participate with her music class and that all of them endorsed her idea and gave her support when needed.

\section{CONCLUSION}

The detailed description of the Salzburg case showed the complexity of such a cooperation project with various partners. All of the project participants were entrusted with different tasks on educational or organizational levels and came up with own, partly overlapping goals 
and expectations. The analysis based on the Venn diagram highlighted the communalities and differences between the project partners. It was interesting to see, that already young students have a big variety of expectations and goals when participating in a cooperation project. To learn about the benefits and difficulties in such a cooperation project is one of the reasons for the teacher training program to implement it in the master curriculum. It is important for future music teachers to know about the possibilities of cooperation with extracurricular partners.

We learned from the remarks of the music teacher that support from the school administration and fellow teachers is a fundamental basis for a successful project. The teacher as one of the key persons in this complex system has to communicate with all project partners and has a lot of educational and organizational responsibilities. In Austria, there is hardly any help offered when teachers want to attend music performances outside of the school, it strongly depends on the commitment and idealism of the teacher even though concert attendances are demanded by the music curriculum.

Funding sources: The European research project "Schools@Concerts" is funded and hosted by the Mozarteum Universty Salzburg, which supports regular research meetings with the research team. No other financial support was given.

Authors' contribution: The author collected and analyzed the data from the Salzburg part of the "Schools@Concerts" research project, which connects extracurricular activities in the Austrian school system with the possibilities of concert attendances. The author adapted the research design for the Salzburg case and was also responsible for the implementation. In addition, the author analyzed the roles and tasks of the participating partners in the cooperation project.

Conflict of interest: The authors declare no conflict of interest.

\section{ACKNOWLEDGMENTS}

No additional acknowledgments.

\section{ABOUT THE AUTHOR}

Andreas Bernhofer holds a $\mathrm{PhD}$ in music education and is assistant professor at the music education department of the Mozarteum University Salzburg, Austria. He studied music education, instrumental teaching and mathematics at the University of Salzburg. His research interests are music didactics, qualitative research in music education and digital media. His dissertation included an empirical study about the concert experiences of young people in classical concerts. Andreas Bernhofer initiated the European research project "Schools@Concerts: Tuning up for the Music Experience" and is the chair of the research team since 2017. Andreas Bernhofer is an elected Board Member of the European Association for Music in School (EAS) since 2017. 


\section{REFERENCES}

Bernhofer, A. (2016a). Die 'edukativen' Erlebnisse eines Konzertbesuchs - oder: Was können Jugendliche durch Konzertbesuche lernen? [The 'educational' experiences of a concert visit - or: What can young people learn through a concert visit?]. Musikerziehung, 69(1), 18-21.

Bernhofer, A. (2016b). Young people experiencing classical concerts. In O. Krämer, \& I. Malmberg (Eds.), Open ears-Open minds. Listening and understanding music (pp. 323-336). Innsbruck: Helbling.

Knaus, H., Peschl, W., Rehorska, W., \& Winter, C. (2013). Kompetenzen in Musik. [Competences in music education]. Musik-Erziehung spezial. Jahrgang 66. Heft 3. Wien.

Mayring, P. (2008). Qualitative Inhaltsanalyse. Grundlagen und Techniken [Qualitative content analysis. Basics and Techniques]. Weinheim: Beltz Verlag.

Oebelsberger, M., \& Bernhofer, A. (2019). Joint venture: University - School - Festival. In M. Oebelsberger, A. Bernhofer, \& G. Sammer (Eds.), Joint (Ad)Venture music. Networking as a challenge for music teachers. Innsbruck: Helbling Verlag.

Schwanse, U. (2003). Familienkonzerte in Kooperation mit Grundschulen-Ein Konzept und seine Wirkungen [Family concerts in cooperation with primary schools-A concept and its impacts]. Paderborn: Univ. Diss.

Yin, R. K. (2009). Case study research. Design and methods. SAGE Publications.

Open Access statement. This is an open-access article distributed under the terms of the Creative Commons AttributionNonCommercial 4.0 International License (https://creativecommons.org/licenses/by-nc/4.0/), which permits unrestricted use, distribution, and reproduction in any medium for non-commercial purposes, provided the original author and source are credited, a link to the CC License is provided, and changes - if any - are indicated. 